\title{
Third Way Interventions in Public Space and Urban Design
}

\author{
Oscar Rodrigo Perilla
}

Pontifical Xaverian University, School of Architecture and Design, Colombia operilla@javeriana.edu.co

\begin{abstract}
As epitomized by the famous rivalry between Jane Jacobs and Robert Moses in the '60s New York, city planning and the understanding of public space has mainly oscillated between two opposing poles: the tidy and organized city planned with a top-down approach by architects using geometry to shape it, on one hand; and the messy and disorganized city, shaped with a bottom-up spirit, lacking planning and allowing the traces of its inhabitants to take place, on the other. This article explores a Third Way in-between these two poles. Analysing different ways how those opposites have appeared in history and different endeavours undertaken to tear them down, it examines projects developed under Stan Allen's concept of infrastructural urbanism, where we explore at Pontifical Xaverian University innovative approaches to urban and public space design that empower inhabitants to shape their own city (bottom-up) whilst maintaining a sense of order and composition through designed structures (topdown) that challenge Leon Battista Alberti's foundational criterion of architectural beauty: you can neither add nor subtract any element without destroying the harmony achieved.
\end{abstract}

Keywords: infrastructural urbanism, public space, innovation, bottom-up, urban design

To cite this article:

Perilla, O. R. (2020) Third Way Interventions in Public Space and Urban Design, The Journal of Public Space, 5(4), 339-352, DOI 10.3289I/jps.v5i4.1406

This article has been reviewed by the Editors and accepted for publication in The Journal of Public Space. This work is licensed under a Creative Commons Attribution - Non Commercial 4.0 International License https://creativecommons.org/licenses/by-nc/4.0/ 


\section{Introduction}

When real estate developer Robert Moses proposed a road through the Greenwich Village in 1955, he met with opposition from one particularly vehement resident: Jane Jacobs (Paletta, 2016). This was the beginning of a decades-long battle that opposed Moses' ambition to create a New York full of big infrastructure works and rationalist and standardized building towers with Jane Jacobs' defence of a neighbourhood life that favours variety and change, consolidating one of the most famous rivalries in urban planning, urban design and the public space of the 20th century.

\section{Oppositions in history}

This opposition of rational and ordered forms against free forms that seem to be generated spontaneously and with a certain lack of order, is anything but new in the history of western culture. The first time it appeared was in the opposition between mousikē and techne back in archaic and early classical Greece. As part of the Dionysian rites, the mousike was a ritualized fusion of poetry, music, and dance that was supported by divine inspiration'. The gods would whisper words to poets, songs to musicians, and movements to dancers (Parcell, 2012, p. 22-23). Contrary to what happened with the concept of techne, mousike was supported and supervised by the muses and directly inspired by the gods: that is, mousike was not something that could be learned (lbid.). On the contrary, techne is defined by Paul Oscar Kristeller precisely as that which can be taught and learned (1990), that whose rules can be understood in a rational way and which therefore can be passed on from generation to generation. While mousike is the materialization of the intentions of gods, techne is the materialization of human reason. This is the reason why, when the Pythagoreans discovered the rational rules -translated into numbers- behind pitch intervals and harmony of music, their countrymen ended up tremendously disappointed (Parcell, 20I2, p. 38).

However, as centuries passed, that rationality would acquire prestige and moral implications. In the 5th century, for example St. Augustine would declare that evil is within what lacks limits, divisions, and order (Boone, 2020 p.35; Tzonis \& Lefaivre, 1986, p. 24). The limits of the rational -that give shape to Euclidean figures- will also be fundamental for Kant in the 18th century, making explicit the opposition between the beautiful and the sublime: the beautiful refers to the form of the object consisting of its definition, what calms and comforts; the sublime to what has no form, that which does not have clear limits and which excites and agitates (Žižek, 1989, p. 202). The word sublime from its very etymology, is directly related to the concept of limit, and specifically to its negation, that is, with the limitlessness or infinity (Meillet \& Ernout 200I); and also, to the forces of nature and the of Dionysian (Doran, 20I5, p. 8). The importance of limits would be taken up again in late 19th century by Heinrich Wölfflin in what would become one of the most important oppositions in the history of art. For him, the "unpainterly" architecture is defined by the pleasure of the "clearly

\footnotetext{
${ }^{1}$ Although there might seem to be a distance between the sublime creation of the inspired artist within a Dionysian rite and the informal configuration of neighborhood life, they both share the same structure: they all operate in an analogous way to nature. As explained ahead, the Dionysian, as well as the sublime are intimately related to nature, and Hernández, Hernández and Niño (2012) show how nature is also related to that city life Jane Jacobs advocated for.
} 
conceived, precise and limited" form (1968, p. 95). While the "painterly" one had something completely unique, "it was capable of giving the impression of the sublime" (lbid., p. 93).

Wölfflin, would consolidate an effort started by his professor Jakob Burckhardt, who was also a professor of Friedrich Nietzsche's, who in turn would use the very context of the Greek Dionysian rites -from which the very concept of mousike arose- to establish an analogous opposition: that between the Apollonian and the Dionysian (Nietzsche, 1999). The Apollonian, referring to Apollo, god of the sun and a symbol of forces of logical order and sobriety; and the Dionysian, referring to Dionysus, god of wine, instincts, nature, and emotions.

Wölfflin's opposition, however, will take place, in a different historical context: The Renaissance and the Baroque. For Wölfflin, Renaissance -the unpainterly architecturecorresponds to a rational order with clearly defined and multiple parts, evoking stasis; the Baroque -the painterly architecture- on the contrary, corresponds to that whose parts become an indistinguishable unified entity, where mases protrude, giving the impression of movement and emotion (1968, p. 29-39).

This opposition of Wölfflin's has been commented on, taken up, expanded, and reinterpreted by several important authors. Karsten Harries, for example, uses the opposition extracting connotations: Renaissance forms defies time through its stasis, becoming eternal but without changes, therefore evoking death; the Baroque, on the contrary, celebrates time, movement and change and therefore evokes life (1998, p. $22 \mathrm{I}-225)$. From a very different perspective, Harries ends up getting to the same opposition that Jacobs identified in the title of her most important book: "The Death and Life of Great American Cities" (1992). Bruno Zevi for his part, will extend Wölfflin's analysis by applying it beyond the original historical boundaries that Wölfflin set to himself, stating that the entire history of architecture evolves in an oscillating movement between the rational Euclidean forms and the romantic organic ones; an idea he illustrates with an helicoid where history ascends from the past to the present showing the different styles in the history of architecture as belonging either to one opposite or to the other (Zevi, 2008, p. 214).

\section{Third Way approaches in history}

Others, however, will recognize the opposition only as an invitation to tear it down. Such is the case of Charles Jencks, who in 1997 wrote: "A totally ordered and disordered art, a completely regular and chaotic environment, are naturally produced by our economic-cultural system. What we want today in architecture and art is something between and, as we will see, at right angles to these extremes" (1997, p. 35). Jencks advocated for a Third Way whose benefits for human well-being are being corroborated by recent studies in the field of cognitive architecture (Ellard, 2015; Sussman, 2014; Urist, 2016). 


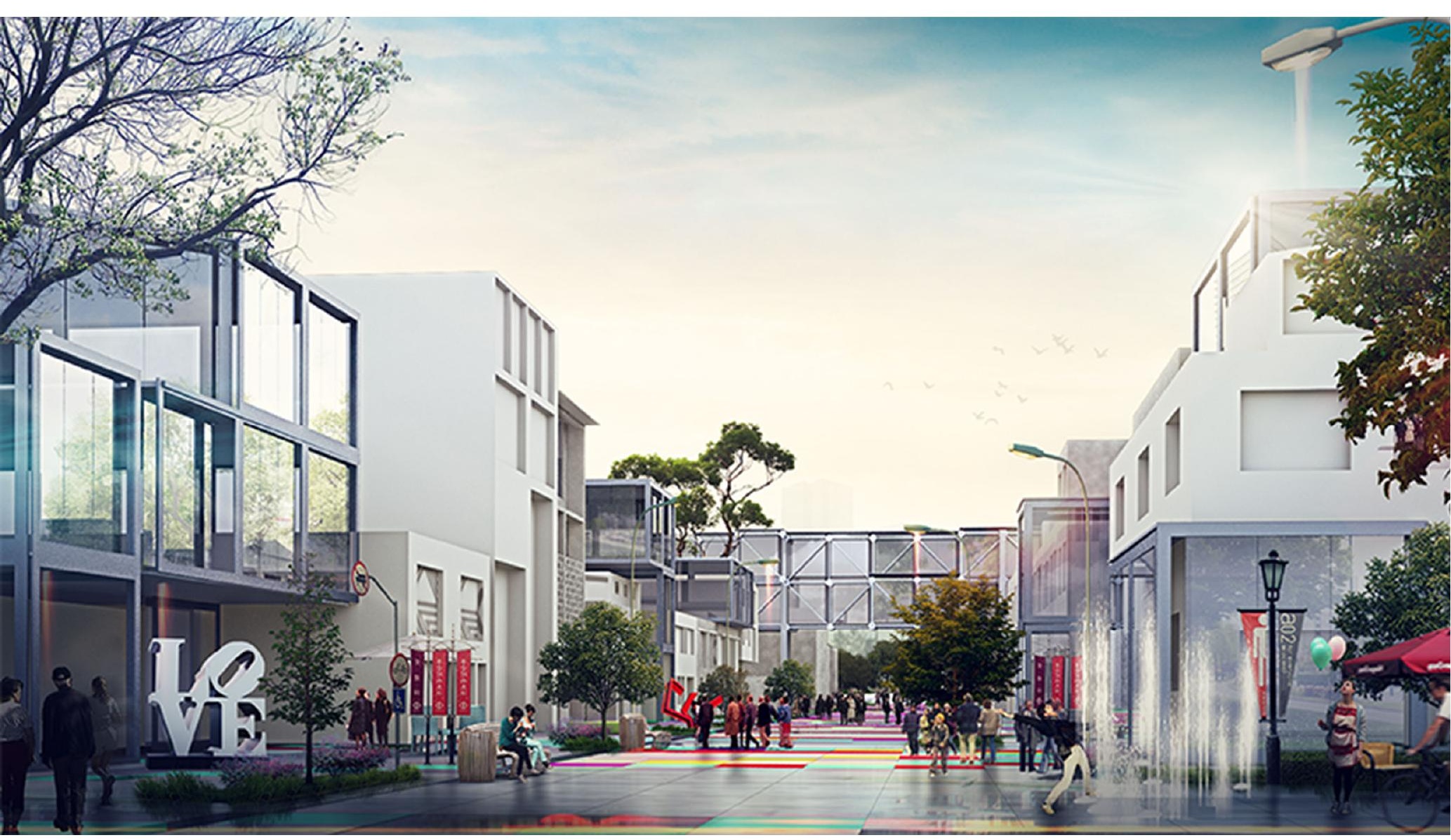

Figure I. Rendered image for project "Infrastructure for Urban Transformation and Adaptation: Strategies for the Potentiation of Bogotá Art District" developed by Maria Alejandra Peña under the author's supervision. Source: Maria Alejandra Peña.

But just as the opposition itself is not new, this call for the exploration of a Third Way is not new either.

As early as the 18th century, English garden designers tried to overturn the opposition between the beautiful and the sublime with the concept of the picturesque ${ }^{22}$; which in turn would help Auguste Choisy understand the configuration of Greek urban ensembles (I899-20I5; Etlin, 1987), from where he ended up influencing Le Corbusier's concept of promenade (Etlin, 1987) and through this, also to a number of important architects of the late 20th and the early 2 Ist centuries. Iñaki Ábalos would explain this phenomenon in a very clear way by declaring about the theoretical body of the picturesque that "its texts often describe better the interests of many contemporary creations than all modern treatises" (2009, p. 7). Ábalos goes further in his analysis and dates the beginning of the resurgence of this picturesque spirit: 1973, "the year that

\footnotetext{
${ }^{2} 18^{\text {th }}$ Century foundational theorist Uvdale Price writes: "the picturesque has a character not less separate and distinct than either the sublime or the beautiful, nor less independent of the art of painting" $(I 8 \mid 0,1: 39)$. The picturesque quits the search for a totalizing geometric order to undertake one for a cinematic experience in space-time, shifting the view of the designer from an aerial one of floor plans to that of the landscape painter: the pedestrian's. For analysis on this concept see also Macarthur, 2007, Bois, 1984, and Marshall, 2002.
} 
marks (...) the abandonment of the attitudes, topics, languages and goals of modernity" (lbid.). He chooses this year as a milestone that represents the end of the validity of modern ideals -those defended by Robert Moses- as it corresponds to the beginning of oil crisis. But another paradigmatic fact has become a more famous symbol of that tipping point: Pruitt-lgoe implosion in St Louis, Missouri on July 15, 1972; which Jencks would call the death of modern architecture (1977, p. 9). This milestone marks a clear triumph for Jane Jacobs and the beginning of the consolidation of the reflection on dwelling in architecture. Dwelling -understood as the possibility of leaving a trace (Benjamin, 1999)- is alien to the pure and closed forms of the rationalist pole precisely because of its immutability. In this new context, and parallel to the picturesque ideals mentioned by Ábalos, architects such as John Habraken will emerge, consolidating another quest for a Third Way that had been forging since the 1960s.

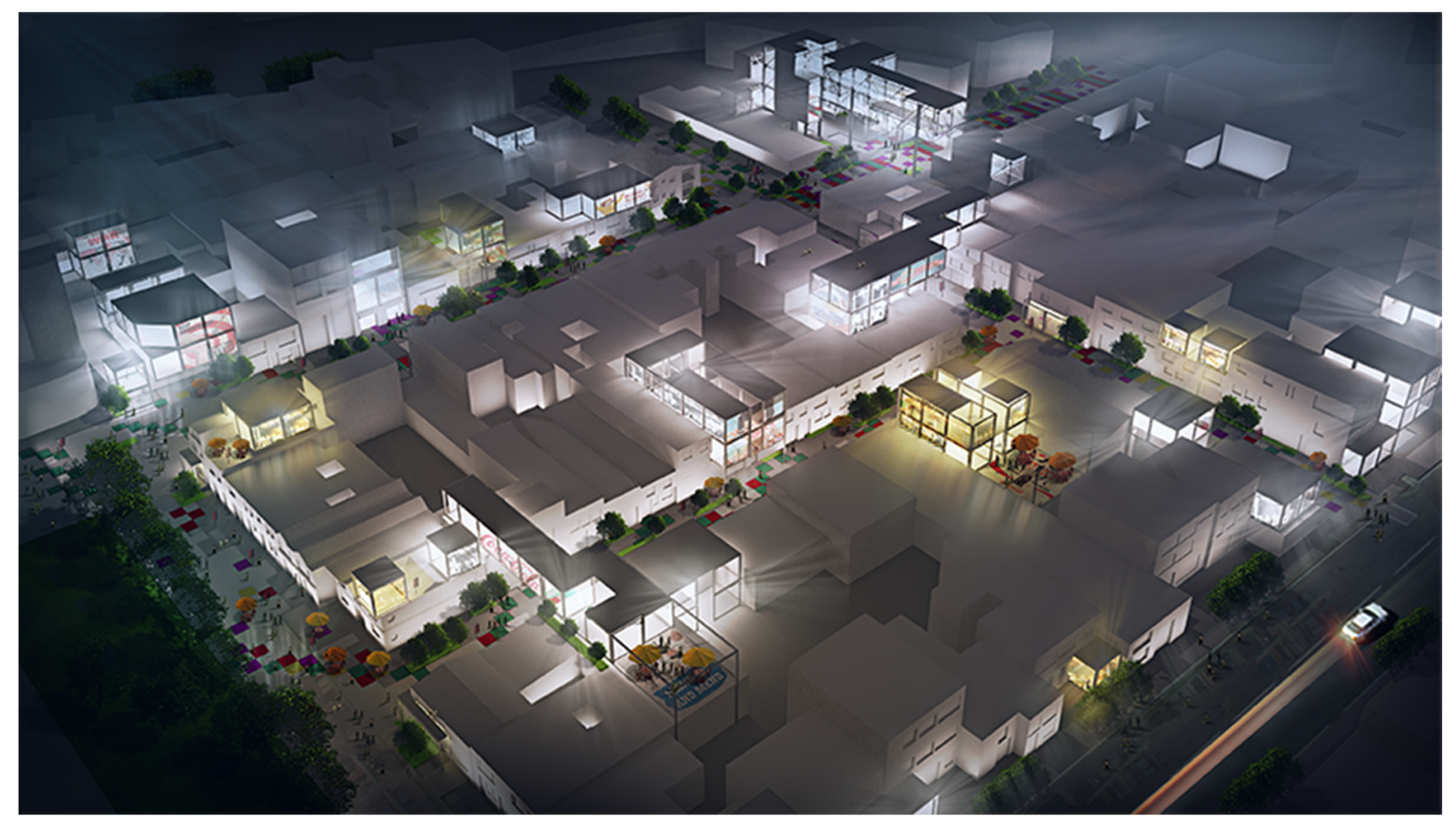

Figure 2. Rendered image for project "Infrastructure for Urban Transformation and Adaptation: Strategies for the Potentiation of Bogotá Art District” developed by Maria Alejandra Peña under the author's supervision. Source: Maria Alejandra Peña.

Habraken's approach was very clever: it played with the very essence of classical architecture. The closed order of classical Greek architecture -a techne-- was made up of two fundamental elements: schema and taxis (Tzonis \& Lefaivre, 1986, p. 9, 18, 27, 28). The first one refers to the form understood as a whole: as a complete and defined mental image. The second one to the relationship mediated by mathematical and geometric rules between the different elements. The Combination results in a clear, but also tremendously closed system. Alberti, in Renaissance, would put it very clearly when explaining his concept of beauty:

"I shall define beauty to be a harmony of all the parts, in whatsoever subject it appears, fitted together with such proportion and connection, that nothing could be added, diminished or altered, but for the worse." (Alberti, I726-I955, VI, ii, p. II3) 

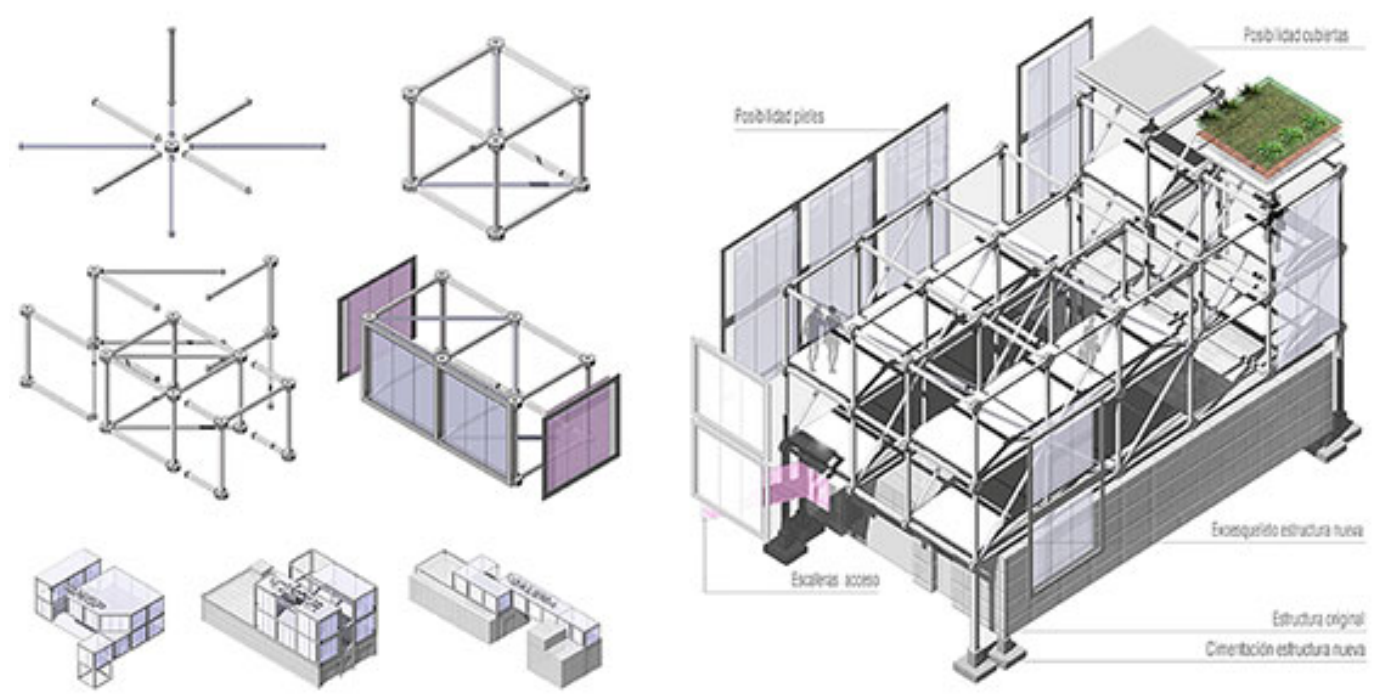

Figure 3. Design development drawings for project "Infrastructure for Urban Transformation and Adaptation: Strategies for the Potentiation of Bogotá Art District" developed by Maria Alejandra Peña under the author's supervision. Source: Maria Alejandra Peña.

Habraken is going to attempt to make of architectural structures, habitable ones -that is, structures able to be affected by the user-; opening the system of classical architecture: maintaining the taxis and getting rid of the schema. He will explain it using language as an analogy:

"The need for a prior image is most keenly felt when we do not trust the form as something to work with. There is nothing wrong with having such an image, but it is not a prerequisite and may be a hindrance. When we speak with other people we need not know what the end result of the conversation will be either. We may come out of the conversation with a better sense of the issue; in fact, we may have changed our mind. When we are concerned about "doing our own thing" and feel we must be on top of the form all the time we cannot relax and trust the process". (Habraken, 1987, p. 6)

This recognition of the importance of a two-way communication and not simply "doing our own thing" will also be highlighted by Zygmunt Bauman quoting Rosenweig:

"(Speech) does not know in advance just where it will end. It takes its cue from others. In fact, it lives by virtue of another's life". (Bauman, 2008, p. 125)

Humberto Maturana, along the same lines, is going to be more explicit by taking that sense of conversation out of the scope of the word-based language. For Maturana, language appears there where a living being coordinates its behaviour with others. The classic example to understand this, mentioned by Maturana himself on several occasions, is the scene in which an observer stands behind a window and sees how two people (whom he cannot hear, but only see) communicate. For the observer, these 
people are clearly communicating, but that is not determined by the use they make of a certain symbolic system, since while the visual plane prevents us from capturing such a symbolic system, it is not crucial to determine that they in fact are (Maturana, 1978; Ortiz-Ocaña, 2015). Maturana raises communication beyond the spoken and written language, to understand it as an interaction between two beings, as a mutual soaking through: a mutual leaving a trace.

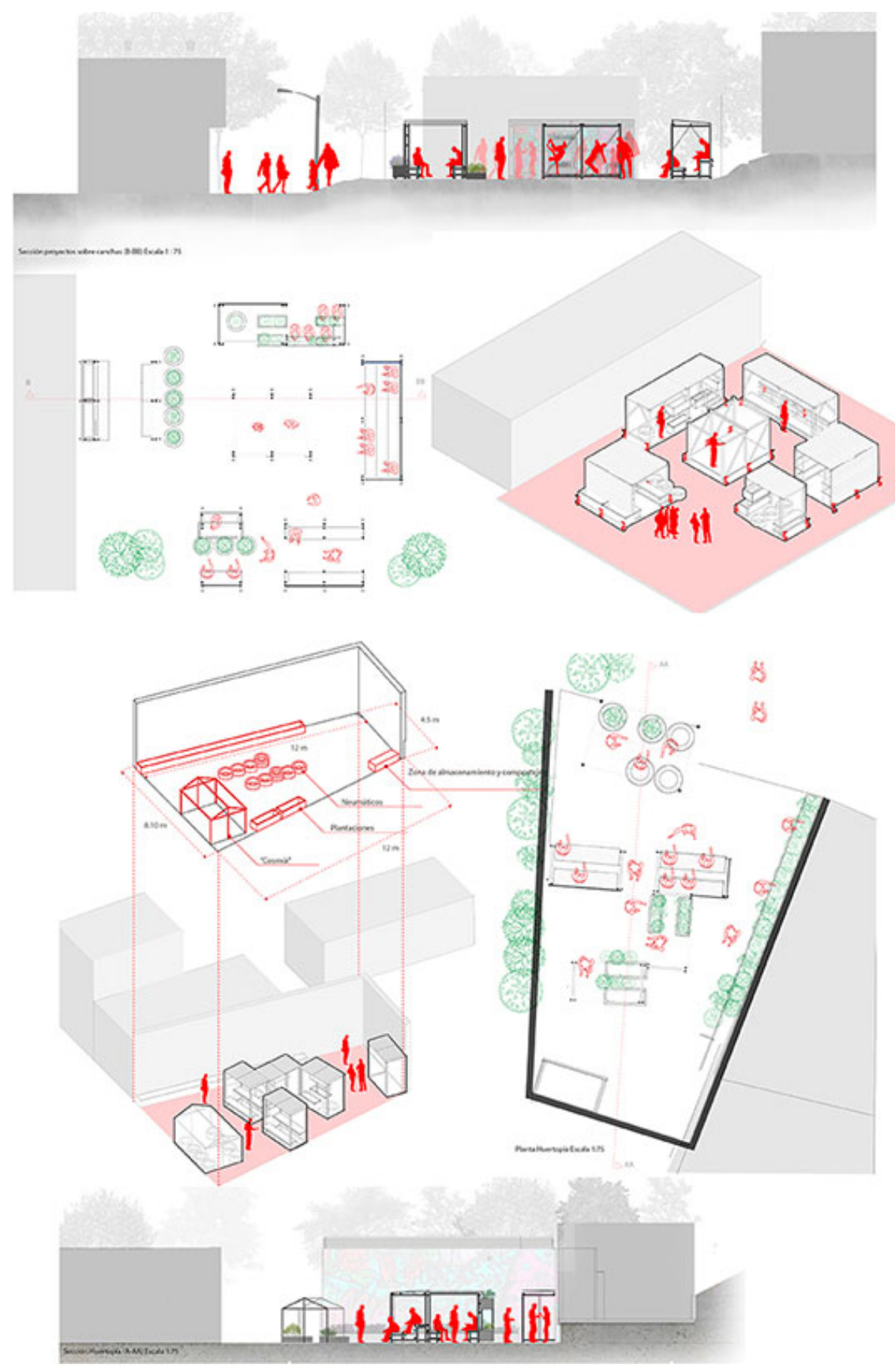

Figure 4. Design development drawings for project "Platform for cultural practices in the popular habitat: Los Laureles, community use and appropriation" developed by Juan Martin Castañeda under the author's supervision. Source: Juan Martin Castañeda. 
Habraken is then going to favour an architecture that opens up to a dialogue through fostering communication between the subject and the object - literally - where one affects the other, where one leaves its trace on the other: although maintaining a clear set of rules of formal configuration.

This form of Third Way will have an important role in contemporary Latin American architecture. Chilean architect Alejandro Aravena (Pritzker Prize laureate in 2016), will create formal structures that become support for future informal modifications of the inhabitants, for example, and Colombian architect Giancarlo Mazzanti will generate a set of rules that articulate the different elements of a composition which behave as modules to be configured according to the specific needs of each particular project.

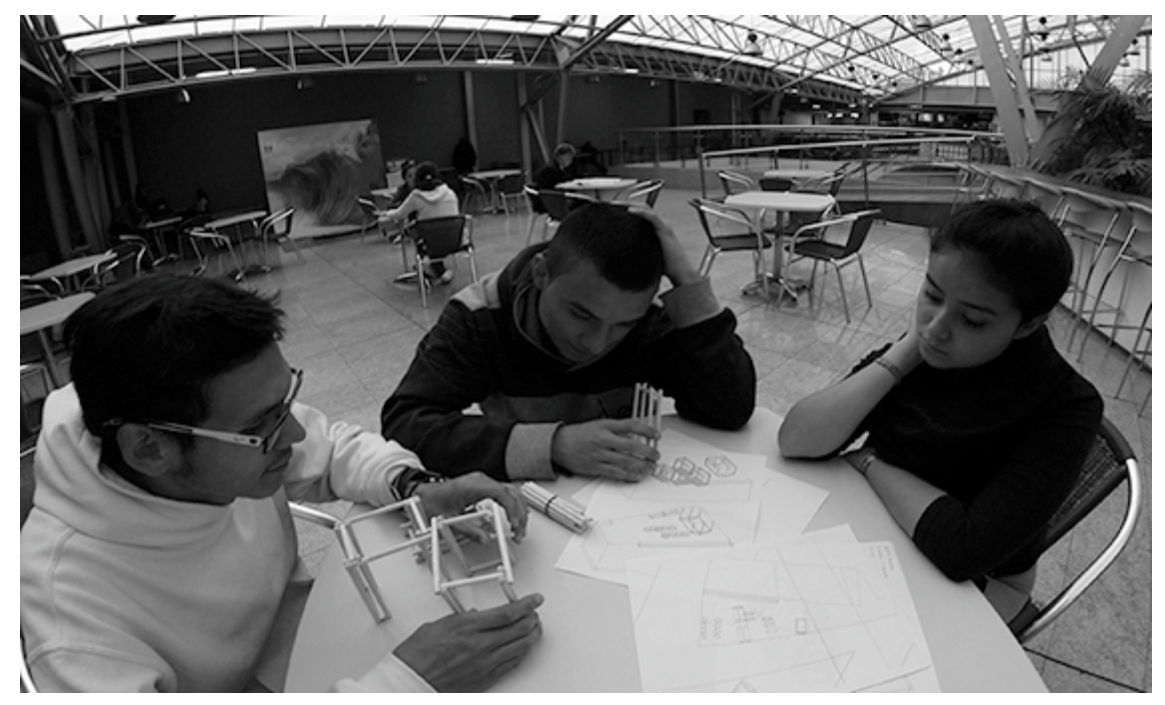

Figure 5. Photography of participatory process for project "Platform for cultural practices in the popular habitat: Los Laureles, community use and appropriation" developed by Juan Martin Castañeda under the author's supervision. Source: Juan Martin Castañeda.

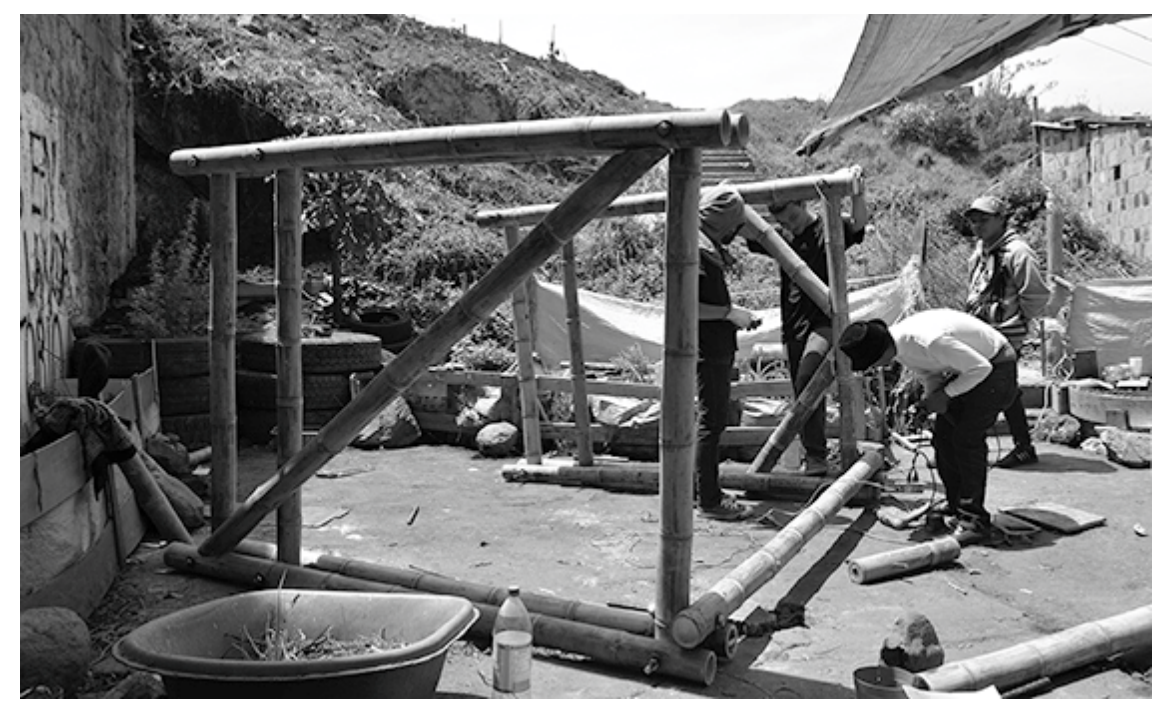

Figure 6. Photography of construction process for project "Platform for cultural practices in the popular habitat: Los Laureles, community use and appropriation" developed by Juan Martin Castañeda under the author's supervision. Source: Juan Martin Castañeda. 


\section{Third Way Explorations in Public Space and Urban Design}

Along these lines, at the Pontifical Xavierian University and within the framework of RIBA II final degree projects, we have been exploring how this idea of spatial configuration systems with clear rules but without a limitation or specific formal definition allows us to address different complex problems commonly found in contemporary Latin American cities; armed with Habraken's concepts, but also taking as a framework another form of Third Way approach: Stan Allen's infrastructural urbanism (1999).

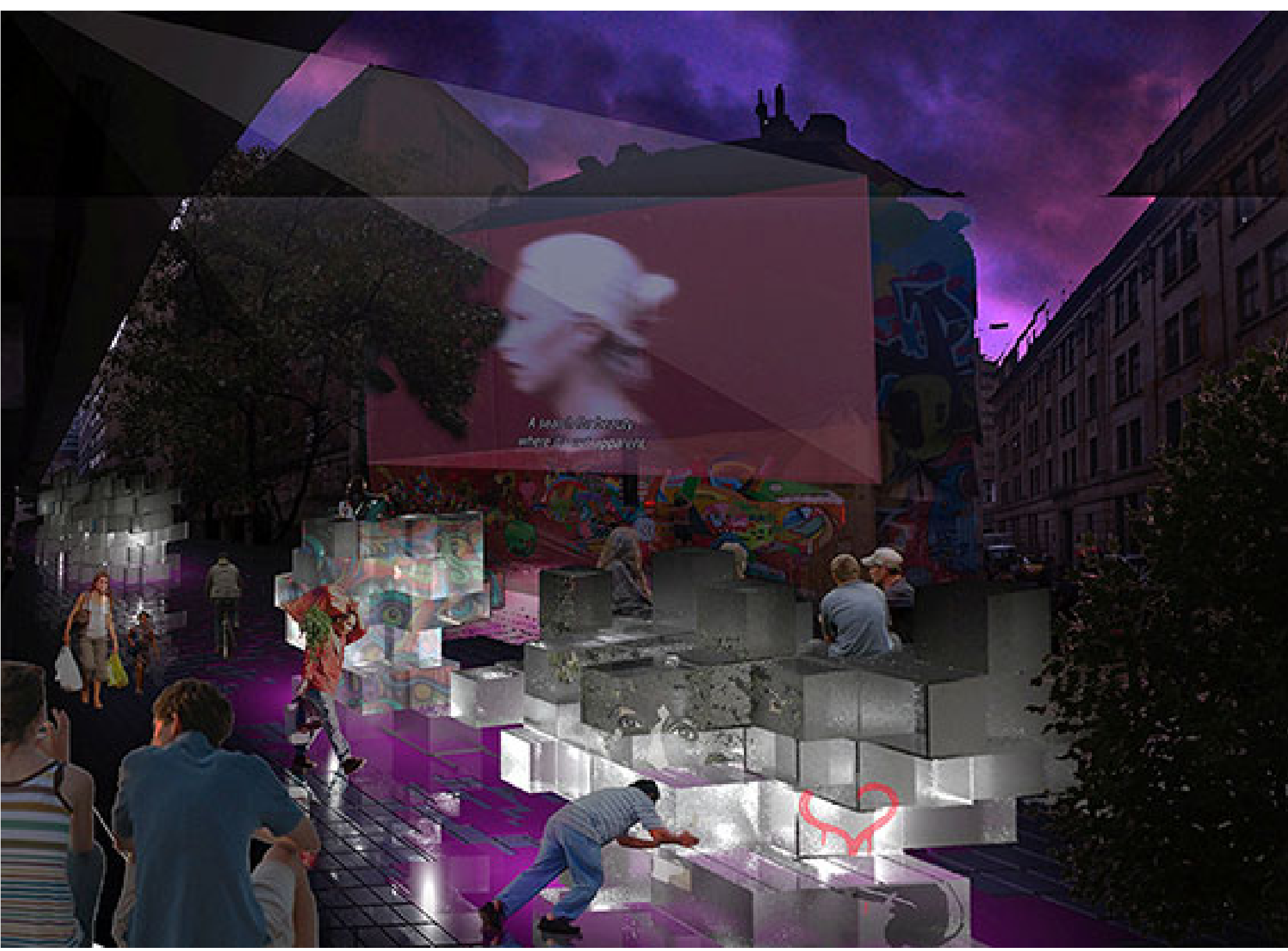

Figure 7. Rendered image for project "Operational Chimeras: The Trace of the Fold in Urban Landscape" developed by Maria Camila Santos under the author's supervision. Source: Maria Camila Santos.

Placing himself a few curves above within Zevi's helicoid, Allen will stay the middle of the opposition between modernity and postmodernity to attempt to refute it. He will defend the importance of the materiality of modernity inherited from the Bauhaus and 
the Werkbund, but he will criticize the creation of autonomous, closed objects: "The second claim is for a practice engaged in time and process, a practice not devoted to the production of autonomous objects, but rather to the production of directed fields in which program, event, and activity can play themselves out" (lbid., p. 52); moving also away from the preconceived form: "material practices deploy an open catalogue of techniques without preconceived formal ends" (Ibid., p. 53).

Quoting Robin Evans paraphrasing Lyotard -and continuing with the analogy of language free of constraints Habraken began- Allen goes on to affirm that introducing architecture to the world of things produces a "volatile, unordered, unpoliceable communication that will always outwit the judicial domination of language" (lbid., p. 52). Taking as a model the regular and static infrastructure that Moses defended, Allen will turn it into a support for the variety of the unexpected that Jacobs paraded for. Paraphrasing Walter Benjamin, Allen will defend "the capacity of certain structures to act as a scaffold for a complex series of events not anticipated by the architect meanings and affects existing outside of the control of a single author that continuously evolve over time" (lbid., p. 54).

It is under these parameters that we have developed a series of projects that tackle problems that require mediation between opposing forces such as formality and informality, emergency and planning, appropriable and ordered public space, and linear and dislocated urban narrative.
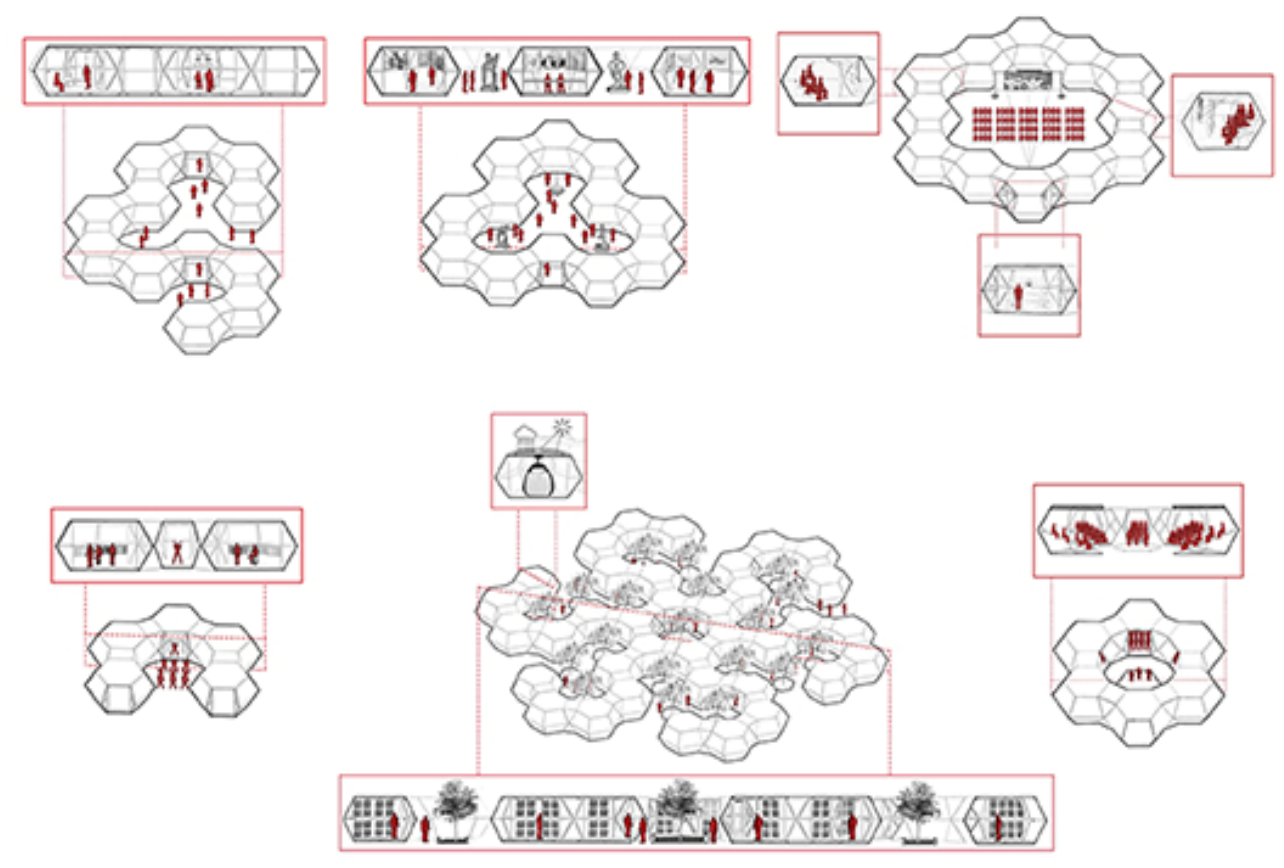

Figure 8. Design development drawings for project "Square as Scene of Shock: Urban Architecture + Cinematography" developed by Sebastián Mejia under the author's supervision. Source: Sebastián Mejia.

Developed under my supervision, the projects "Infrastructure for Urban Transformation and Adaptation: Strategies for the Potentiation of Bogotá Art District" 
(completed 2016) developed by Maria Alejandra Peña (Figures I, 2 \& 3), "Platform for cultural practices in the popular habitat: Los Laureles, Community Use and Appropriation" (completed 2016) developed by Juan Martin Castañeda (Figures 4, 5 \& 6), "Operational Chimeras: The Trace of the Fold in Urban Landscape" (completed 2014) developed by Maria Camila Santos (Figure 7), and "Square as Scene of Shock: Urban Architecture + Cinematography" (completed 2017) developed by Sebastián Mejia (Figures 8, 9 \& 10), all make use of Third Way approaches that have as a theoretical framework Allen's concept of infrastructural urbanism and Habraken's concept of support and infill.

Peña's work (Figures I, 2 \& 3), explores an in-between of the opposing forces of emergent requirements against preconceived planning. Aiming at strengthening and contributing to the development of the consolidating Bogota Art District, the challenge of the project was to intervene in an area of spontaneous generation of galleries, cafes, and restaurants in a neighbourhood that is in the process of consolidation as a new art hub in Bogotá, and where former residential structures were converted into improvised spaces for cultural and commercial uses. The proposal consisted on generating modular structures of 'bars and joints' type that would climb like a virus on top of the existing houses providing adequate spaces for the new uses. These structures, although had a permanent character, could be removed and moved according to the changing needs that happened to arise at every specific time and they were program free, so that users would adapt them to whichever use they would give them.

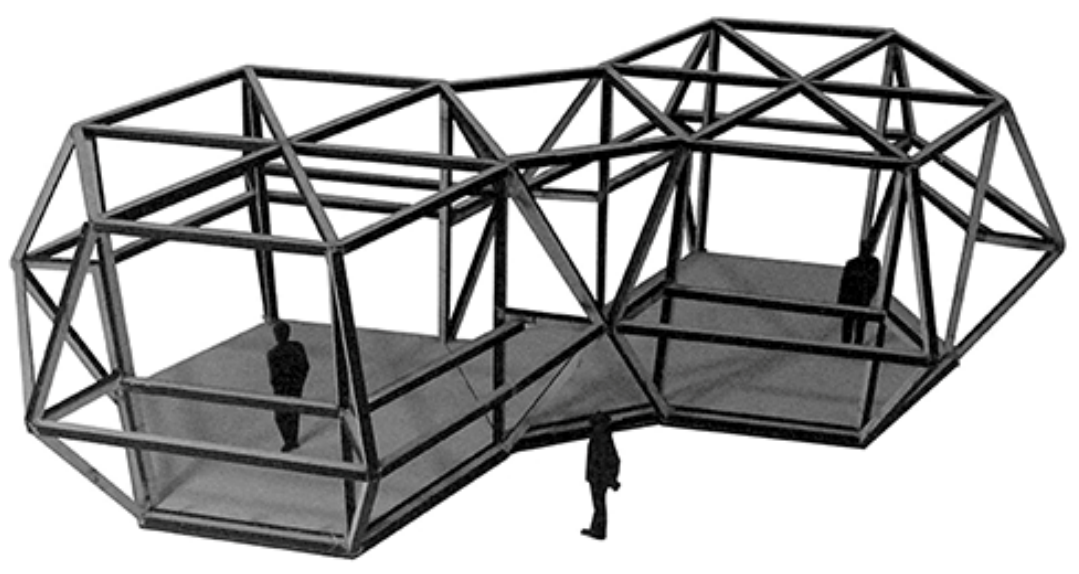

Figure 9. Photography of model for project "Square as Scene of Shock: Urban Architecture + Cinematography" developed by Sebastián Mejia under the author's supervision. Source: Sebastián Mejia.

Castañeda's work (Figures 4, 5 \& 6) addresses the opposition between formality and informality, tackling the question of how to implement interventions in public space within an informal context understanding the particular way how popular communities inhabit their own public space and fostering community cohesion. Developed alongside members of the popular neighbourhood Los Laureles in Ciudad Bolivar, an impoverished district of Bogotá -where it was implemented- the project consisted on the creation of a neutral platform that materialized in a system of easily replicable and low-cost self-construction modules built in guadua, developed with the participation of 
young members of the community (Figure 5). The platform, either as a single element or as multiple combined modules, could house multiple and changing uses. The different elements of the system were designed to be built and managed by the community itself and an actual module was implemented and inhabited by the community.

Santos' work (Figure 7) tackles the opposition of appropriable against ordered public space, mediating between the emergent forces behind inhabitants drive to leave traces in the city and the institutional duty of fostering a sense of order. The project consisted on regular elements with in-built mechanisms that allowed them to be moved by the citizens. Lit form the inside and designed to be painted it was designed to become graffiti-friendly structures that celebrated rather than repelled urban art.

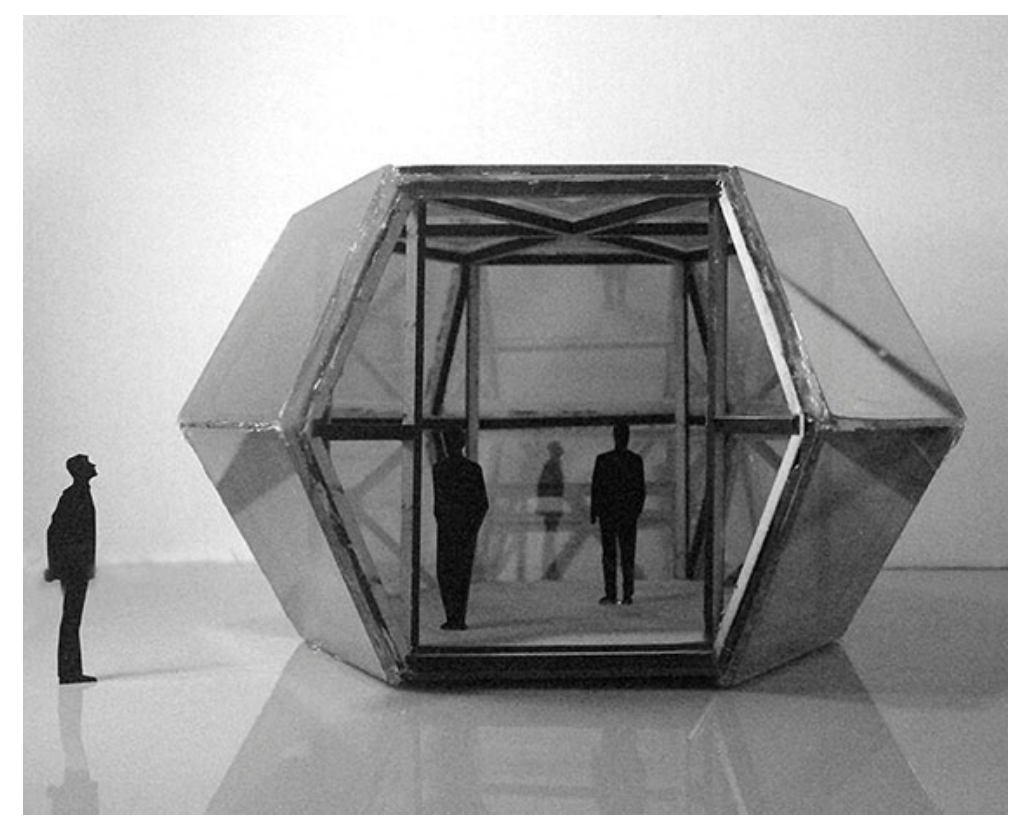

Figure 10. Photography of model for project "Square as Scene of Shock: Urban Architecture + Cinematography” developed by Sebastián Mejia under the author's supervision.

Source: Sebastián Mejia.

And Mejia's work (Figures 8, 9 \& 10), addresses dislocated urban narratives in the city as opposed to linear narratives where there is no offer of surprises, exploring the relationship between architecture and cinema -with the help of Bernard Tschumi's concept of shock - to explore ways to generate revitalization in urban spaces. The project consists of a system of modular devices, that appear unexpectedly in different public spaces of Bogotá, combining in different ways, creating different urban niches and housing different uses.

Challenging the closed definition of beauty that the rationalist pole inherited from classical architecture, but acknowledging the importance of a sense of order in public space and urban design, while at the same time, taking apart the differences behind Moses and Jacobs rivalry, these four projects show the enormous ongoing potential of Third Way approaches to public space and urban design for innovative interventions within the realm of contemporary architecture, and especially within the context of the Latin American city and the demanding challenges it faces today. 


\section{References}

Ábalos, I. (2009). Naturaleza y Artificio: El Ideal Pintoresco en la Arquitectura y el Paisajismo Contemporáneos. Barcelona: Editorial Gustavo Gili.

Alberti, L. B. (1726-1955). On Architecture, Trans. James leoni. London Facsimile ed.

Allen, S. (1999). Infrastructural Urbanism. Points and Lines Diagrams and Projects for the City. New York: Princeton Architectural Press.

Bauman, Z. (2008). Liquid Love: On the Frailty of Human Bonds. Maiden, MA: Polity Press

Benjamin, W. (1999). The Arcades Project, trans. Howard Eiland \& Kevin McLaughlin. Cambridge, MA. \& London: Belknap Press.

Bois, Y. A. (1984). A Picturesque Stroll around "Clara-Clara". October, 29, pp. 32-62.

Choisy, A. (I899-2015). Histoire de l'architecture, Tome I. London: Facsimile Publisher.

Doran, R. (2015). The Theory of the Sublime from Longinus to Kant. Cambridge: Cambridge University Press.

Ellard, C. (2015). Places of the Heart: The Psychogeography of Everyday Life. New York: Bellevue Literary Press.

Etlin, R. A. (1987). Le Corbusier, Choisy, and French Hellenism: The Search for a New Architecture. The Art Bulletin, 69 (2), pp. 264-278.

Habraken, J. (1987). The Control of Complexity. Places, 4 (2), pp. 3-I5.

Harries, K. (1998). The Ethical Function of Architecture. Cambridge, MA: The MIT Press.

Hernández, I., Hernández-Garcia J. \& Niño, R. (2012). Alternative Views of the City:

Complexity, Sustainability, and Everyday Practices. Revista Bitácora Urbano Territorial, 20 (I), pp. 67-77.

Jacobs, J. (1992). The Death and Life of Great American Cities. New York: Vintage.

Jencks, C. (1977). The Language of Post-Modern Architecture. New York: Rizzoli.

Jencks, C. (1997). The Architecture of the Jumping Universe: A Polemic: how Complexity Science is Changing Architecture and Culture. Winterbourne, Berkshire: Academy Editions.

Kristeller, P. O. (1990). The Modern System of the Arts. In Renaissance Thought and the Arts. Princeton: Princeton University. 
Marshall, D. (2002). The Problem of the Picturesque. Eighteenth-Century Studies, 35(3), pp. 4I3437.

Macarthur, J. (2007). The Picturesque Architecture, Disgust and Other

Irregularities. New York: Routledge.

Maturana, H. R. (1978). Cognition. In P.M: Hejl, W.K: Köck \& g. roth (eds.) Wahrnehmung und Kmommunikation, pp. I I-32. Frankfurt: Peter Lang.

Meillet, A. \& Ernout, A. (200I). Sublimis. In Dictionnaire étymologique de la langue latine: Histoire des mots. Paris: Les Belles Lettres.

Nietzsche, F. (1999). The Birth of Tragedy and Other Writings. Cambridge, UK: Cambridge University Press.

Ortiz-Ocaña, A. (20I5). La Concepción de Maturana Acerca de la Conducta y el Lenguaje Humano. Revista CES Psicología, 8(2), PP. 182-199.

Paletta, A. (2016). Story of cities \#32: Jane Jacobs vs Robert Moses, battle of New York's urban titans. The Guardian. [Viewed: Oct 12, 2020]. Available at: https://www.theguardian.com/cities/2016/apr/28/story-cities-32-new-york-jane-jacobsrobert-moses

Parcell, S. (20I2). Architecture as Technē. In Four Historical Definitions of Architecture. Montreal: McGill-Queen's University Press.

Price, U. (1810). Essays on the Picturesque as Compared with the Sublime and the Beautiful; and, on the Use of Studying Pictures, for the Purpuse of Improving Real Landscape 3 vols. London: J. Mawman.

Sussman, A. (20I4). Cognitive Architecture: Designing for How We Respond to the Built Environment. London: Routledge.

Tzonis, A. \& Lefaivre, L. (1986) Classical Architecture: The Poetics of Order. Cambridge, MA: The MIT Press.

Urist, J. (2016). The Psychological Cost of Boring Buildings. The Cut. [Viewed: Oct I2, 2020]. Available at: https://www.thecut.com/2016/04/the-psychological-cost-of-boringbuildings.html

Zevi, B. (2008). El Lenguaje Moderno de la Arquitectura. Barcelona: Editorial Poseidón. 